\title{
RANGE EXTENSION OF THE EASTERN COTTONTAIL RABBIT (SYLVILAGUS FLORIDANUS) IN QUINTANA ROO, MEXICO
}

\author{
Mircea G. Hidalgo-Mihart ${ }^{1,5}$, Rugieri Juárez-López ${ }^{1}$, Alejandro Jesús-de la Cruz ${ }^{1}$, \\ Yaribeth Bravata-de la Cruz ${ }^{1}$, Jesús Iglesias-Hernández ${ }^{2}$, Freddy Pérez-Garduza ${ }^{1}$, \\ Christian A. Delfín-Alfonso ${ }^{3}$, and Alberto González-Gallina ${ }^{4}$
}

\begin{abstract}
AвSTRACT.-The eastern cottontail rabbit (Sylvilagus floridanus; ECR) is highly adaptable to human activities and widely distributed across the Yucatan Peninsula. However, the eastern part of the peninsula, where the Mexican state of Quintana Roo is located, had only marginal records. Herein, we report the collection of one individual and the observation of 7 different individuals of the ECR in northeastern Quintana Roo. These records increase the range of the species by $66 \mathrm{~km}$ into the eastern portion of the Yucatan Peninsula. The absence of previous records of the species-even though the mammalian fauna of the region has been surveyed both historically and recently_probably indicates that the species has expanded its range. Further research is required to determine factors that contribute to the species' range expansion as well as its effects on other species.
\end{abstract}

Resumen.-El Conejo cola de algodón (Sylvilagus floridanus; CCA) es una especie de conejo de talla mediana, altamente adaptable a las actividades humanas que tiene una amplia distribución en la Península de Yucatán. Sin embargo, el este de la Península donde se localiza el estado de Quintana Roo presenta sólo registros marginales. En esta nota reportamos una colecta y siete observaciones del CCA en el noreste de Quintana Roo que incrementan el área de distribución de la especie en $66 \mathrm{~km}$. La ausencia de registros previos a pesar de que existen prospecciones de mamíferos en la región, probablemente indica que la especie ha incrementado su área de distribución. Es necesario determinar los factores que podrían estar favoreciendo la expansión de la especie en la región, así como los posibles efectos en las comunidades naturales.

The eastern cottontail rabbit (Sylvilagus floridanus; ECR) is a medium-sized rabbit (average total length $=427.0 \mathrm{~mm}$, range 395 to $456 \mathrm{~mm}$ ) with an extensive distribution that goes from southern Canada to the north of South America (Chapman et al. 1980). The ECR is a species usually found in a wide variety of disturbed, early successional or shrub-dominated habitats that include an abundance of forage and dense understory cover. This habitat preference has allowed the ECR to increase its populations as a response to the land-use change of forested areas to agriculture (Chapman and Litvaitis 2003).

On the Yucatan Peninsula in Mexico, cottontail rabbits have been recorded since the late Pleistocene (Arroyo-Cabrales et al. 2010), and the ECR has been commonly found in all the mammal surveys performed in the state of Yucatan (Elliot 1907, Nelson 1909, Gaumer 1917, Jones et al. 1974, EscobedoCabrera and Lorenzo 2011; Fig. 1). However, on the eastern part of the Yucatan Peninsula, particularly in the state of Quintana Roo, many mammal surveys failed to find the species (Pozo de la Tijera and Escobedo-Cabrera 1999, González-Romero and López-González 2000, Faller-Menéndez et al. 2005, UrquizaHaas et al. 2011), and the surveys that recorded the species found the ECR only in a limited number of localities in western Quintana Roo (Navarro et al. 1990, Cervantes et al. 1997, Escobedo-Cabrera and Lorenzo 2011; Fig. 1). Also, use of the ECR by subsistence hunters in the Yucatan Peninsula is common in the areas where the species is present (León and Montiel 2008, Reid 2009), but the ECR has not been reported as being hunted on the eastern Yucatan Peninsula (e.g., Jorgenson 1995, Quijano-Hernández and Calmé 2002, Ramírez-Barajas and Naranjo-Piñera 2007), indicating it is probably absent in that area.

As part of a study to determine the effect of a new road on native wildlife, we performed

\footnotetext{
${ }^{1}$ División Académica de Ciencias Biológicas, Universidad Juárez Autónoma de Tabasco, C.P. 86040, Villahermosa, Tabasco, México

${ }^{2}$ Sistemas Estratégicos para la Gestión Ambiental SEGA, S.A. de C.V., C.P. 03230, Benito Juárez, Ciudad de México, México.

${ }^{3}$ Instituto de Investigaciones Biológicas, Universidad Veracruzana, C.P. 91190, Xalapa, Veracruz, México.

${ }^{4}$ Instituto de Ecología A.C. Red de Ambiente y Sustentabilidad, C.P. 91070, Xalapa, Veracruz, México.

5Corresponding author. E-mail: mhidalgo@yahoo.com
} 


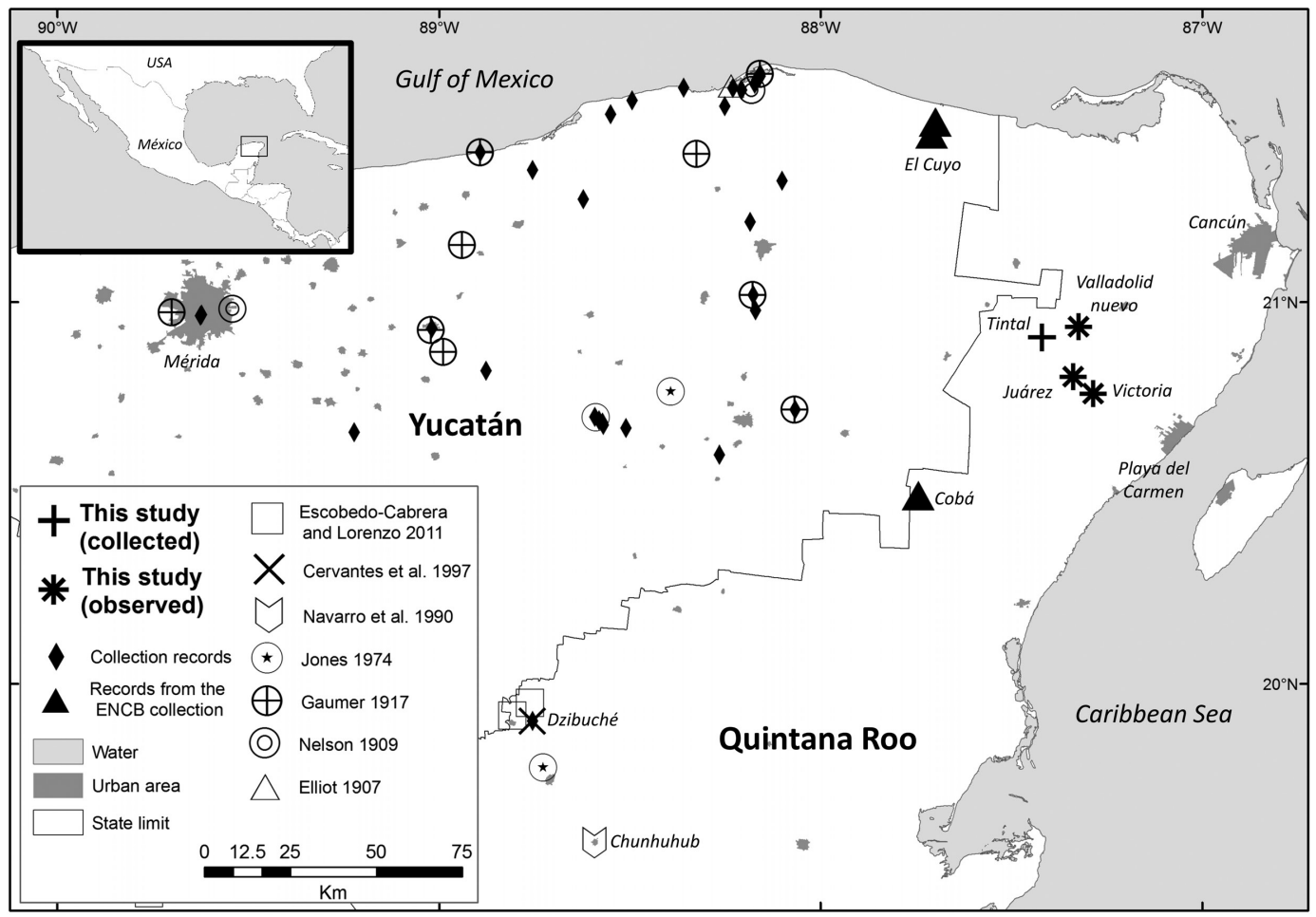

Fig. 1. Locations of the collected and observed new records of the eastern cottontail (Sylvilagus floridanus) in the northeast portion of the Yucatan Peninsula. Collection records were obtained by searching the Global Biodiversity Information Facility (GBIF) and the Mammal Networked Information System (MANIS). Literature records were obtained from Elliot (1907), Nelson (1909), Gaumer (1917), Jones (1974), Navarro et al. (1990), Cervantes et al. (1997), and Escobedo-Cabrera and Lorenzo (2011). Filled triangles highlight the locations of the Cobá and El Cuyo records from the Colección de Mamíferos de la Escuela Nacional de Ciencias Biológicas (ENCB).

extensive fieldwork in northeastern Quintana Roo during 2013 to 2015. During the fieldwork, we observed the ECR on 7 occasions in the area and collected one that was road killed. These records document first-time observations of the species in the eastern portion of Quintana Roo and expanded the ECR range by $66 \mathrm{~km}$ from the previously known records of the species (Fig. 1).

The study area was in the Solidaridad and Lázaro Cárdenas municipalities of Quintana Roo, México (Fig. 1). The area is mainly flat with an average altitude of $10 \mathrm{~m}$ asl. Climate in the region is warm (mean annual temperature $26-28{ }^{\circ} \mathrm{C}$ ) with summer precipitation (1000-1500 mm per year; Instituto Nacional de Estadística y Geografía 2015). The original vegetation in the area was tropical evergreen forest (Rzedowski 2006), but due to regular hurricanes and slash-and-burn agricultural fires, most of the area is covered by a gradient of successional stages that include induced pastures and seasonal agriculture, secondgrowth forests, and mature tropical forests.

The main goal of the study was to identify the diversity and abundance of mammals in an area where a new road was proposed for construction. To accomplish these objectives, we worked intensively from November 2012 to May 2015, driving and walking through the study area to observe the presence of wildlife. Also, we set 56 camera trap stations inside the tropical evergreen forests and the mature second-growth forests of the region (30 Digital Cuddeback Attack, Non Typical, Inc., De Pere, WI; 26 Digital LTL Acorn 5210 A, OldBoys Outdoors, Stone Mountain, GA). The cameras were active $24 \mathrm{~h}$ per day for at least 65 days per year for a total effort of 7280 camera days (one camera day equals one camera station in operation for $24 \mathrm{~h}$ ). During the fieldwork on 16 April 2014, we collected one 


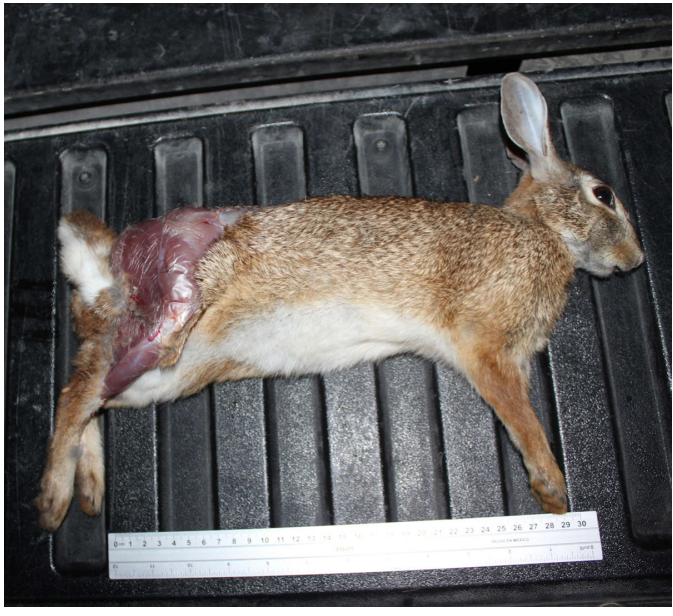

Fig. 2. Photograph of the eastern cottontail (Sylvilagus floridanus) collected as a roadkill on Federal road number 80 Mérida-Cancun. This image is deposited in the Photograph Collection of Vertebrates "Alvar González Christen" in the Instituto de Investigaciones Biológicas, Universidad Veracruzana (Mammals Cat. IIB-UVMam 0008f). Photograph by Alejandro Jesús-de la Cruz.

adult female ECR that was road killed along Federal road number 80 Mérida-Cancun in an area surrounded by induced grasslands, $3 \mathrm{~km}$ east of the town of Tintal, Quintana Roo (20.9078, -87.4188; total length $465 \mathrm{~mm}$, tail length $81 \mathrm{~mm}$, ear length $83 \mathrm{~mm}$, hind foot length $116 \mathrm{~mm}$; Figs. 1, 2). We identified the specimen as an ECR by the size and the presence of the white tail, which is the most conspicuous character that differentiates the ECR and the forest rabbit (Sylvilagus gabii), the only other rabbit whose distributional range is close to the study area (Reid 2009). The collected specimen (skull, skin, and partial skeleton) was deposited in the Mammal Collection of the Instituto de Investigaciones Biológicas, Universidad Veracruzana (VER.-MAM-19110-06 SEMARNAT) with the catalog number IIB-UVMam 04234. Additionally, on 7 different occasions between 2013 and 2014, we observed solitary ECRs in open habitats (induced grasslands or early stages of secondgrowth forest) located along routes that we were traveling in the study area (Fig. 1, Table 1). Due to the distance from the observer to the ECRs, we were not able to identify the sexes of the observed individuals. We did not capture any photographs with the camera traps.

We performed an intensive search for ECR records from the states of Yucatan and
Quintana Roo in publications and web-based mammal collections databases (e.g., Global Biodiversity Information Facility GBIF, http:// www.gbif.org; Mammal Networked Information System, MANIS http://manisnet.org). We found 20 previously published records of the ECR in both states ( 5 in Quintana Roo and 15 in Yucatan; Fig. 1) and 37 unique collection records (2 from Quintana Roo and 35 from Yucatan; Fig. 1). We found that the closest ECR records to our records were the Cobá and El Cuyo specimens, which are deposited in the Colección de Mamíferos de la Escuela Nacional de Ciencias Biológicas-Instituto Politécnico Nacional (ENCB; Catalog numbers 16560, 34219, and 42609). The measured distances between the specimen that we collected and the 2 easternmost records in Cobá and El Cuyo were $64 \mathrm{~km}$ and $55 \mathrm{~km}$, respectively (Fig. 1). Of the ECRs observed during the study, the records at the Nuevo Valladolid locality were the farthest from both specimens deposited in the ENCB $(66 \mathrm{~km}$ from Cobá and $67 \mathrm{~km}$ from El Cuyo; Table 1, Fig. 1), making these observations the easternmost location of the ECR on the Yucatan Peninsula.

ECRs in Quintana Roo have been recorded only from localities in the western portion of the state, close to the Yucatan State border (Navarro et al. 1990, Cervantes et al. 1997, Escobedo-Cabrera and Lorenzo 2011; ENCB 16560; Fig. 1). Mammal surveys performed in eastern Quintana Roo did not find the species (e.g., Pozo de la Tijera and Escobedo-Cabrera 1999), and there are no records of the species as prey for subsistence hunters in the state (e.g., Jorgenson 1995, Quijano-Hernández and Calmé 2002, RamírezBarajas and Naranjo-Piñera 2007). These 2 pieces of evidence suggest that the new observed records could be part of a species range expansion in the region.

The land-use change from forested areas to agriculture has been proposed to benefit the ECR (Chapman and Litvaitis 2003). Also, previous work in southeastern Mexico has clustered the ECR within a group of species that will increase in population size and range due to land-use change from forest to open anthropized habitats (Cuarón 2000). Our observations that the ECR in the study area was in open habitats (induced grasslands and early stages of secondary forests; Table 1), together with the fact that we did not get any 


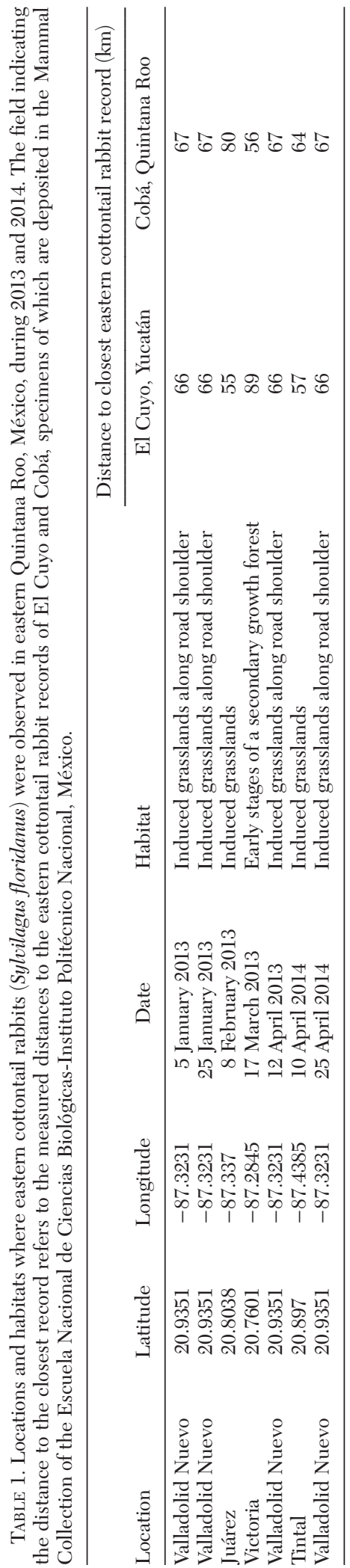

camera-trap photos of the species in forested areas, could support this account.

In the state of Quintana Roo from the year 2000 to 2013, more than 330,000 ha of mature forests were transformed to induced grasslands and second-growth forests (Ellis et al. 2017). The northeastern portion of the state still suffers the loss of large tracts of tropical forests mostly due to expansion of subsistence agriculture, urban expansion associated with growth of tourist activities in the cities of Cancún and Playa del Carmen, and the effect of hurricanes that frequently cross the region, causing damage to the forest and favoring forest fires (Ellis et al. 2017). The transformation of the forest to open (croplands and induced grasslands) and partially open habitats (second-growth forests) could be contributing to the expansion of the ECR to new localities in the region.

The ECR is commonly used by subsistence hunters in the Yucatan Peninsula and Central America, but it is also considered a nuisance species in the region because it feeds on corn (Reid 2009). Human-induced and natural habitat transformation in the northeastern portion of Quintana Roo may increase habitat availability for the ECR. The consequential expansion of the species could pose a threat of damage to croplands of the region. It is important to understand the potential role that species such as the ECR play while expanding their original distribution ranges due to habitat changes in the Yucatan Peninsula and how these changes affect the mammal community dynamics in the region, the potential use of the species as a resource for human subsistence hunters, and the potential for increasing human-wildlife conflicts.

\section{ACKNOWLEDGMENTS}

This work was possible with the financial support granted to Sistemas Estratégicos para la Gestión Ambiental SEGA S.A. de C.V. by Ingenieros Civiles Asociados (División Infraestructura ICAi) and Consorcio del Mayab, through the wildlife monitoring project for the road "Ramales Cedral-Tintal, Tintal-Playa del Carmen con una longitud de $54 \mathrm{~km}$ en el estado de Quintana Roo, México.” The División Académica de Ciencias Biológicas de la Universidad Juárez Autónoma de Tabasco, and the Mammal Collection of the Instituto de 
Investigaciones Biológicas, Universidad Veracruzana granted logistical support for the success of the project. We thank personnel of the Colección de Mamíferos de la Escuela Nacional de Ciencias Biológicas-Instituto Politécnico Nacional (ENCB) for providing information on the ECR specimens in the collection.

\section{Literature Cited}

Arroyo-Cabrales, J., O.J. Polaco, E. Johnson, and I. Ferrusquía-Villafranca. 2010. A perspective on mammal biodiversity and zoogeography in the Late Pleistocene of Mexico. Quaternary International 212:187-197.

Cervantes, F.A., C. Lorenzo, and M.D. Engstrom. 1997. New records of the eastern cottontail (Sylvilagus floridanus) and black-tailed jackrabbit (Lepus californicus) in Mexico. Texas Journal of Science 49:76.

Chapman, J.A., J.G. Hockman, and M.M. OJeda C. 1980. Sylvilagus floridanus. Mammalian Species 136:1-8.

Chapman, J.A., and J.A. Litvaitis. 2003. Eastern cottontail. Sylvilagus floridanus and allies. Pages 101-125 in G.A. Feldhamer, B.C. Thompson, and J.A. Chapman, editors, Wild mammals of North America. 2nd edition. Johns Hopkins University Press, Baltimore, MD.

CUARón, A.D. 2000. Effects of land cover changes on mammals in a neotropical region: a modeling approach. Conservation Biology 14:1676-1692.

ELliot, D.G. 1907. A catalogue of the collection of mammals in the Field Columbian Museum. Field Columbian Museum Zoological Series 115:1-694.

Ellis, E.A., J.A. Romero Montero, and I.U. Hernández GómEz. 2017. Deforestation processes in the state of Quintana Roo, Mexico: the role of land use and community forestry. Tropical Conservation Science 10:1940082917697259.

Escobedo-Cabrera, E., and C. Lorenzo. 2011. Nuevos registros de Sylvilagus floridanus en la Península de Yucatán, México. Therya 2:279-283.

Faller-Menéndez, J.C., T.A. UrQuiza-HaAs, C. Chávez, S. Johnson, and G. Ceballos. 2005. Registros de mamíferos en la reserva privada El Zapotal, en el noreste de la península de Yucatán. Revista Mexicana de Mastozoología 9:128-140.

Gaumer, G.F. 1917. Monografía de los mamíferos de Yucatán. Departamento de Talleres Gráficos de la Secretaría de Fomento, México.

González-Romero, A., AND C.A. López-GonZÁlez. 2000. Capítulo 10, Aspectos generales sobre la ecología de los vertebrados del jardín botánico. Pages 125-140 in O. Sánchez-Sánchez and G.A. Islebe, editors, El jardín botánico Dr. Alfredo Barrera Marín; fundamentos y estudios particulares. ECOSUR-CONABIO, México, D.F.

Instituto Nacional de Estadística y Geografía. 2015. Anuario estadístico y geográfico de Quintana Roo. Instituto Nacional de Estadística y Geografía y Gobierno del Estado de Quintana Roo. Aguascalientes, México.

Jones, J.K., H.H. Genoways, and J.D. Smith. 1974. Annotated checklist of mammals of the Yucatan Peninsula, Mexico. III. Marsupialia, Insectivora, Primates, Edentata, Lagomorpha. Mammalogy Papers: University of Nebraska State Museum 23:1-12.

JoRgEnson, J.P. 1995. Maya subsistence hunters in Quintana Roo, Mexico. Oryx 29:49-57.

León, P., and S. Montiel. 2008. Wild meat use and traditional hunting practices in a rural Mayan community of the Yucatan Peninsula, Mexico. Human Ecology 36:249-257.

Navarko, L.D., T. JiméneZ, and J. Jú́rez. 1990. Los mamíferos de Quintana Roo. Pages 351-450 in L.D. Navarro and J.O. Robinson, editors, Diversidad biológica en la Reserva de la Biosfera de Sian Ka’an, Quintana Roo. Centro de Investigaciones de Quintana Roo. Chetumal, Quintana Roo, México.

Nelson, E.W. 1909. The rabbits of North America. North American Fauna 29:1-314.

Pozo de la Tijera, C., and J.E. Escobedo-Cabrera. 1999. Mamíferos terrestres de la Reserva de la Biosfera de Sian Ka’an, Quintana Roo, México. Revista de Biología Tropical 47:1-12.

Quijano-Hernández, E., and S. Calmé. 2002. Patrones de cacería y conservación de la fauna silvestre en una comunidad maya de Quintana Roo, México. Etnobiología 2:1-18.

Ramírez-Barajas, P., and E. Naranjo-Piñera. 2007. La cacería de subsistencia en una comunidad de la zona maya, Quintana Roo, México. Etnobiologia 5:65-85.

REID, F. 2009. A field guide to the mammals of Central America and southeast Mexico. 2nd edition. Oxford University Press, New York, NY.

Rzedowski, J. 2006. Vegetación de México. Comisión Nacional para el Conocimiento y Uso de la Biodiversidad, Distrito Federal, México.

Urquiza-Haas, T., C.A. Peres, and P.M. Dolman. 2011. Large vertebrate responses to forest cover and hunting pressure in communal landholdings and protected areas of the Yucatan Peninsula, Mexico. Animal Conservation 14:271-282.

Received 30 June 2017 Accepted 2 October 2017 Published online 20 December 2017 